Dikirim: 23 Agustus 2016 Diterbitkan: 1 April 2017

\title{
Faktor risiko loss to follow up terapi ARV pada pasien HIV
}

\section{Risk factors for loss to follow up of antiretroviral therapy in HIV patients}

Listy Handayani ${ }^{1}$, Riris Andono Ahmad ${ }^{1}$, Yanri Wijayanti Subronto ${ }^{2}$

\begin{abstract}
Purpose: This study aimed to determine risk factors for loss to follow-up of antiretroviral therapy among HIV-infected patients in Dr. Sardjito Yogyakarta, 2011-2014. Methods: A retrospective cohort study was conducted involving 499 HIV patients. Observations were conducted for four years using medical records. Data analysis was performed using Kaplan-Meier and Cox proportional hazards regression tests. Results: There were 190 loss to follow-up patients. Risk factors for loss to follow-up of ARV therapy were: a student $(A H R=2.42 ; 95 \% \mathrm{Cl}=1.20-4.89)$, the distance $\geq 10 \mathrm{~km}(A H R=1.58$; $95 \% \mathrm{Cl}=1: 09$ to $2: 31$ ), using health insurance (AHR $=1.67 ; 95 \% \mathrm{Cl}=1: 11$ to 2:51) and homosexual as a protective factor of loss to follow-up of antiretroviral therapy $(\mathrm{HR}=0: 49 ; 95 \% \mathrm{Cl}=0.30-0.80)$. Conclusion: Being a college student, the distance between home and ARV service $\geq 10 \mathrm{~km}$ and using health insurance were the risk factors of loss to follow-up of ARV treatment. Adherence counseling for students, cooperation with the drug taking supervisor and decentralization ARV service, as well as effective and efficient services for patients who use health insurance need to be strengthened.
\end{abstract}

Keywords: loss to follow-up; ARV; HIV

\footnotetext{
${ }^{1}$ Departemen Biostatistik, Epidemiologi dan Kesehatan Populasi, Fakultas Kedokteran, Universitas Gadjah Mada (listy.handayani@mail.ugm.ac.id)

2 Departemen Ilmu Penyakit Dalam, Fakultas Kedokteran, Universitas Gadjah Mada
} 


\section{PENDAHULUAN}

Kasus baru pengidap HIV (Human Immunodeficiency Virus) di seluruh dunia dengan jumlah kasus baru sebanyak 2,1 juta. Data menunjukkan 7 dari 10 wanita hamil hidup dengan HIV. Pasien yang dilaporkan menerima terapi ARV sebanyak 17 juta (1).

Kasus HIV di Indonesia cenderung mengalami peningkatan, hingga tahun 2015 mencapai 184,929 orang dan kasus AIDS mencapai 68,197 orang. Jumlah kasus AIDS terbanyak pada laki-laki (54\%), faktor risiko heteroseksual (64.5\%) dan golongan umur terbanyak pada 20-29 tahun (32\%). Angka kematian (CFR) AIDS menurun dari $1.22 \%$ pada tahun 2014 menjadi $0.67 \%$ pada tahun 2015 (2). Hingga September 2015, Provinsi DIY menempati urutan ke 8 prevalesi HIV AIDS tertinggi di Indonesia dengan prevalensi 26,5 per 100.000 penduduk. Secara ku- mulatif jumlah kasus HIV AIDS sebesar 3.146 penderita HIV-AIDS, dengan 2.862 orang masih hidup, 272 telah meninggal dan 12 orang tidak diketahui statusnya (3).

Salah satu upaya yang dilakukan untuk memperpanjang harapan hidup ODHA (Orang dengan HIV AIDS) adalah dengan penggunaan kombinasi obat antiretroviral (ARV). Meskipun belum mampu menyembuhkan HIV secara menyeluruh dan menambah tantangan dalam hal efek samping serta resistansi kronis terhadap obat, namun secara dramatis terapi ARV menurunkan angka kematian dan kesakitan, meningkatkan kualitas hidup ODHA dan meningkatkan harapan masyarakat, sehingga pada saat ini HIV dan AIDS telah diterima sebagai penyakit yang dapat dikendalikan dan tidak lagi dianggap sebagai penyakit yang menakutkan (4).

Secara umum pemberian terapi ARV diberikan dalam bentuk kombinasi yang harus dikonsumsi seumur hidup. ODHA yang menerima terapi ARV rentan mengalami loss to follow up karena hal ini memiliki hubungan yang erat dengan ketidakpatuhan ODHA dalam mengonsumsi ARV (5). Loss to follow up terapi ARV adalah pasien yang tidak berkunjung ke klinik VCT untuk pengobatan selama 90 hari sejak kunjungan terakhir atau putus berobat selama 3 bulan terturut-turut (6).

ODHA yang loss to follow up akan memberikan efek, baik itu efek klinis maupun program terapi ARV. Pada tingkatan klinis, kelanjutan terapi ARV ODHA yang loss to follow up tidak akan dapat dievaluasi. ODHA yang berhenti mengikuti terapi akan berisiko kematian yang lebih besar. Dari 402 pasien yang loss to follow up, sebanyak 66.7\% telah meninggal (7). Hal ini disebabkan sistem imun yang awalnya dikendalikan oleh terapi ARV akan menjadi semakin buruk, sehingga ODHA rentan terhadap infeksi oportunistik dan berakibat pada kematian (8). Selain itu, HIV akan menjadi resisten dan kebal terhadap ARV. Akibatnya jika ODHA memutuskan mengikutI kembali terapi, kemungkinan ODHA akan mengalami kegagalan terapi di lini 1 sehingga harus beralih ke lini 2. Apabila ODHA sudah sampai di lini 2 tetapi kembali terjadi kegagalan terapi, ini berarti ARV sudah tidak mampu mengendalikan replikasi HIV. Dengan kata lain, akan terjadi resistensi obat sehingga ARV tidak lagi dapat berfungsi atau terjadi kegagalan terapi ARV (9). Penelitian membuktikan bahwa faktor yang berhubungan dengan loss to follow up terapi ARV pada ODHA adalah penderita umur $<32$ tahun, ketiadaan pengawas minum obat (PMO) dan faktor risiko penularan sebagai pekerja seks (10).

RSUP Dr. Sardjito merupakan salah satu rumah sakit rujukan HIV AIDS di Provinsi DIY. Jumlah kasus loss to follow up terapi ARV pada pasien HIV di RSUP Dr. Sardjito sejak tahun 2008-2012 tercatat sebanyak 127 kasus. Untuk mengetahui faktor penyebab loss to follow up di rumah sakit tersebut perlu dilakukan penelitian mengenai faktor risiko loss to follow up terapi ARV di RSUP Dr. Sardjito.

\section{METODE}

Penelitian non eksperimental ini menggunakan pendekatan kuantitatif dan merupakan jenis penelitian analitik observasional. Penelitian ini menggunakan rancangan retrospective cohort study dengan waktu pengamatan selama empat tahun sejak tahun 2011-2014. Data yang dikumpulkan adalah data sekunder menggunakan form pengumpulan data yang diperoleh dari data rekam medis dan register ARV pada 22 April-21 Juni 2016 di RSUP Dr. Sardjito Provinsi DIY. Populasi dan sampel pada penelitian ini bejumlah 499 pasien HIV (total sampling).

Analisis data menggunakan Kaplan-Meier untuk mengetahui besaran masalah loss to follow up dan cox proportional hazards regression untuk mengetahui apakah umur, jenis kelamin, pendidikan, pekerjaan, jarak dengan layanan ARV, cara pembayaran, kelompok risiko tinggi, kadar CD4, stadium penyakit (WHO-stage), koinfeksi dan regimen ARV yang dapat meningkatkan risiko loss to follow up terapi ARV pada pasien HV di RSUP Dr. Sardjito tahun 2011-2014. 


\section{HASIL}

Hasil pengamatan tahun 2011-2014 pada penelitian ini menunjukkan bahwa dari 61,9\% pasien yang tidak mengalami loss to follow up, meliputi 52,5\% pasien masih melanjutkan pengobatan sampai pengamatan selesai, 4,0\% pasien meninggal sebelum pengamatan selesai dan 5,4\% pasien pindah rumah sakit (rujuk keluar) sebelum pengamatan selesai.

Tabel 1 menunjukkan pasien yang mengalami loss to follow up pada penelitian ini sebanyak 38.1\%. Karakteristik sosiodemografi pasien yang mengalami loss to follow up tahun 2011-2014 adalah umur $\leq 35$ tahun $(54,3 \%)$, laki-laki $(72,1 \%)$, pendidikan menengah (68,4\%), bekerja di bidang swasta (43,7\%), jarak rumah dengan layanan ARV $\geq 10 \mathrm{~km}$ (61,8\%) dan cara pembayaran dengan umum (65,2\%).

Tabel 1 Karakteristik sosiodemografi pasien HIV di RSUP Dr. Sardjito

\begin{tabular}{|c|c|c|c|}
\hline Variabel & $\begin{array}{l}\text { Jumlah } \\
(\mathrm{N}=499)\end{array}$ & $\begin{array}{c}\text { Loss to Follow } U_{1} \\
n=190(38.1 \%)\end{array}$ & $\begin{array}{c}\text { Tidak Loss to } \\
\text { Follow Up } \\
\text { n=309 }(61.9 \%)\end{array}$ \\
\hline \multicolumn{4}{|c|}{ Umur (Tahun) $(n=499, \%)$} \\
\hline$\leq 35$ & $306(61,3)$ & $103(54,3)$ & $203(65,7)$ \\
\hline $36-45$ & $110(22,1)$ & $43(22,6)$ & $67(21,7)$ \\
\hline$\geq 46$ & $83(16,6)$ & $44(23,2)$ & $39(12,6)$ \\
\hline \multicolumn{4}{|l|}{ Jenis Kelamin } \\
\hline Perempuan & $136(27,3)$ & $53(27,9)$ & $83(26,9)$ \\
\hline Lak-laki & $363(72,7)$ & $137(72,1)$ & $226(73,1)$ \\
\hline \multicolumn{4}{|c|}{ Pendidikan $(n=489, \%)$} \\
\hline Rendah & $69(14,1)$ & $36(19,3)$ & $33(10,9)$ \\
\hline Menengah & $344(70,3)$ & $128(68,4)$ & $216(71,5)$ \\
\hline Tinggi & $76(15,5)$ & $23(12,3)$ & $53(17,5)$ \\
\hline \multicolumn{4}{|c|}{$\begin{array}{l}\text { Pekerjaan } \quad(n=479, \\
\%)\end{array}$} \\
\hline Tidak bekerja & $88(18,4)$ & $32(17,5)$ & $56(18,9)$ \\
\hline Mahasiswa & $49(10,2)$ & $19(10,4)$ & $30(10,1)$ \\
\hline Swasta & $240(50,1)$ & $80(43,7)$ & $160(54,1)$ \\
\hline PNS/TNI/Polri & $23(4,8)$ & $5(2,7)$ & $18(6,1)$ \\
\hline $\begin{array}{l}\text { Buruh/Petani/La } \\
\text { innya }\end{array}$ & $79(16,5)$ & $47(25,7)$ & $32(10,8)$ \\
\hline \multicolumn{4}{|c|}{ Jarak Rumah dengan Layanan ARV (n=494, \%) } \\
\hline$<10 \mathrm{Km}$ & $213(43,1)$ & $71(38,2)$ & $142(46,1)$ \\
\hline$\geq 10 \mathrm{Km}$ & $281(56,9)$ & $115(61,8)$ & $116(53,9)$ \\
\hline \multicolumn{4}{|c|}{$\begin{array}{l}\text { Cara Pembayaran } \\
(n=489, \%)\end{array}$} \\
\hline Umum & $341(69,7)$ & $122(65,2)$ & $219(72,5)$ \\
\hline $\begin{array}{l}\text { Jaminan } \\
\text { Kesehatan }\end{array}$ & $148(30,3)$ & $65(34,8)$ & $83(27,5)$ \\
\hline
\end{tabular}

Tabel 2 menunjukkan karakteristik perilaku dan kondisi klinik pasien yang mengalami loss to follow up tahun 2011-2014 adalah kelompok risiko tinggi heteroseksual (77,2\%), kadar CD4 $<100$ sel/mm3 (54,5\%), WHO-stage III/IV (57,2\%), koinfeksi >1 (43,9\%) dan menggunakan regimen ARV AZT+3TC+NVP (35,3\%).
Tabel 2 Karakteristik perilaku dan kondisi klinis pasien HIV di RSUP Dr. Sardjito

\begin{tabular}{|c|c|c|c|}
\hline Variabel & umlah $(\mathrm{N}=499)$ & $\begin{array}{c}\text { Loss to } \\
\text { Follow Up } \\
\mathrm{n}=190 \\
(38.1 \%)\end{array}$ & $\begin{array}{c}\text { Tidak Loss } \\
\text { to Follow } \\
\text { Up } \\
\mathrm{n}=309 \\
(61.9 \%)\end{array}$ \\
\hline \multicolumn{4}{|c|}{ Kelompok Risiko Tinggi $(n=450, \%)$} \\
\hline Heteroseksual & $308(68.4)$ & $125(77.2)$ & $183(65.5)$ \\
\hline Homoseksual & $119(26.4)$ & $26(16.0)$ & $93(32.3)$ \\
\hline IDU/Tatto & $23(5.1)$ & $11(6.8)$ & $12(4.2)$ \\
\hline \multicolumn{4}{|l|}{ Kadar CD4 (n=478, \%) } \\
\hline$<100$ & $250(52.3)$ & $97(54.5)$ & $153(51.0)$ \\
\hline $100-199$ & $76(15.9)$ & $28(15.7)$ & $48(16.0)$ \\
\hline$\geq 200$ & $152(31.8)$ & $53(29.8)$ & $99(33.0)$ \\
\hline \multicolumn{4}{|c|}{ WHO-Stage $(n=494, \%)$} \\
\hline $\mathrm{I} / \mathrm{II}$ & $248(50.2)$ & $80(42.8)$ & $168(54.7)$ \\
\hline III/IV & $246(49.8)$ & $107(57.2)$ & 139 (45.3) \\
\hline \multicolumn{4}{|c|}{ Adanya Koinfeksi (n=497, \%) } \\
\hline Tidak ada & $114(22.9)$ & 39 (39.6) & $75(24.3)$ \\
\hline 1 & $175(35.2)$ & $67(35.4)$ & $108(35.1)$ \\
\hline$>1$ & $208(41.8)$ & 83 (43.9) & $125(40.6)$ \\
\hline \multicolumn{4}{|c|}{ Regimen ARV (n=498, \%) } \\
\hline TDF+3TC (FTC)+EFV & $161(32.3)$ & $61(32.1)$ & $100(32.5)$ \\
\hline $\mathrm{TDF}+3 \mathrm{TC}(\mathrm{FTC})+\mathrm{NVP}$ & $20(4.0)$ & 7 (3.7) & $13(4.2)$ \\
\hline $\mathrm{AZT}+3 \mathrm{TC}+\mathrm{EFV}$ & 93 (18.7) & $41(21.6)$ & 52 (16.9) \\
\hline $\mathrm{AZT}+3 \mathrm{TC}+\mathrm{NVP}$ & $199(40.0)$ & 67 (35.3) & 132 (42.9) \\
\hline $\mathrm{d} 4 \mathrm{~T}+3 \mathrm{TC}+\mathrm{EFV}$ & $9(1.8)$ & $7(3.7)$ & $2(0.6)$ \\
\hline $\mathrm{d} 4 \mathrm{~T}+3 \mathrm{TC}+\mathrm{NVP}$ & $16(3.2)$ & $7(3.7)$ & $9(3.0)$ \\
\hline
\end{tabular}

Gambar 1 menunjukkan analisis survival. Hasil Insidence Rate (IR) loss to follow up terapi ARV pada pasien HIV di RSUP dr. Sardjito tahun 2011-2014 adalah 1.71 per 100 person month. Median survival time $50 \%$ loss to follow up terjadi pada bulan ke 48,2.

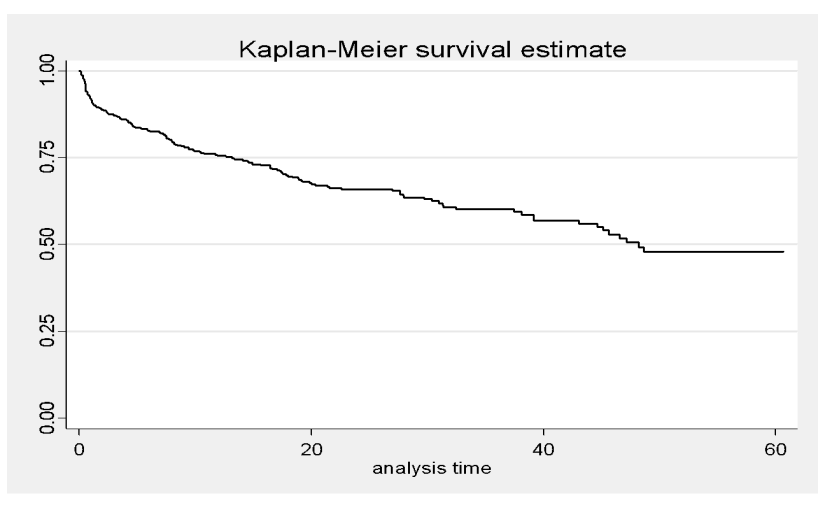

Gambar 1 Kurva Kaplan Meier untuk loss to follow up terapi ARV

Kurva Kaplan Meier menunjukkan persentase pasien HIV yang mengalami loss to follow up dimulai pada bulan ke 1 , cenderung mengalami peningkatan hingga bulan ke 48,2 dan menetap pada bulan ke 49 hingga akhir pengamatan. Survival time 50\% loss to follow up terjadi pada bulan ke-48.

Analisis bivariabel menunjukkan bahwa umur, pekerjaan, jarak rumah dengan layanan ARV, cara pembayaran, kelompok risiko tinggi dan WHO stage signifikan secara statistik dan klinis berisiko terhadap loss to follow up terapi ARV pada pasien HIV. 
Umur $\geq 46$ tahun 1,46 kali berisiko kejadian loss to follow up terapi ARV pada pasien HIV dibandingkan umur lainnya. Pasien yang berprofesi sebagai petani/buruh/lainnya 1,80 kali berisiko untuk mengalami loss to follow up. Jarak rumah $\geq 10 \mathrm{~km}$ dengan layanan ARV 1.52 kali berisiko terhadap kejadian loss to follow up terapi ARV pada pasien HIV dibandingkan jarak <10 km. Pasien yang mempunyai jaminan kesehatan dalam melakukan terapi ARV 1,47 kali berisiko terhadap kejadian loss to follow dibandingkan dengan pasien umum. Pasien dengan kelompok risiko tinggi homoseksual 51\% lebih rendah mengalami loss to follow up dibandingkan pasien dengan kelompok risiko tinggi lain. Pasien dengan WHO-stage III/IV 1,54 kali berisiko terhadap kejadian loss to follow up terapi ARV dibandingkan pasien dengan WHO-stage I/II.

Tabel 3 menunjukkan dari 8 variabel, hanya terdapat 4 variabel yang signifikan secara statistik dan klinis terhadap loss to follow up. Pekerjaan sebagai mahasiswa 2,42 kali berisiko terhadap kejadian loss to follow up terapi ARV dibandingkan dengan jenis pekerjaan lain. Jarak rumah $\geq 10 \mathrm{~km}$ dengan layanan ARV 1,58 kali berisiko terhadap kejadian loss to follow up terapi ARV pada pasien HIV dibandingkan jarak $<10$ km. Pasien yang mempunyai jaminan kesehatan dalam melakukan terapi ARV 1.67 kali berisiko terhadap kejadian loss to follow dibandingkan dengan pasien umum. Faktor risiko homoseksual sebagai faktor protektif loss to follow up pada pasien HIV.

Tabel 3. Model akhir analisis multivariabel faktor risiko loss to follow up terapi ARV Pasien HIV (2011-2014)

\begin{tabular}{|c|c|c|c|}
\hline Variabel & Adjusted HR & 95\%CI & p-value \\
\hline \multicolumn{4}{|l|}{ Pekerjaan } \\
\hline Tidak bekerja & & Ref & \\
\hline Mahasiswa & 2,42 & $1,20-4,89$ & 0,01 \\
\hline Swasta & 1,28 & $0,75-2,19$ & 0,36 \\
\hline PNS/TNI/Polri & 0,52 & $0,17-1,58$ & 0,25 \\
\hline Buruh/Petani & 1,80 & $0,99-3,28$ & 0,05 \\
\hline \multirow{2}{*}{\multicolumn{4}{|c|}{$\begin{array}{l}\text { /Lainnya } \\
\text { Jarak Rumah dengan Layanan ARV }\end{array}$}} \\
\hline & & & \\
\hline$<10 \mathrm{Km}$ & & Ref & \\
\hline$\geq 10 \mathrm{Km}$ & 1,58 & $1,09-2,31$ & 0,01 \\
\hline \multicolumn{4}{|l|}{ Cara } \\
\hline \multicolumn{4}{|l|}{ Pembayaran } \\
\hline Umum & & Ref & \\
\hline $\begin{array}{l}\text { Jaminan } \\
\text { Kesehatan }\end{array}$ & 1,67 & $1,11-2,51$ & 0,01 \\
\hline \multicolumn{4}{|c|}{ Kelompok Risiko Tinggi } \\
\hline Heteroseksual & & Ref & \\
\hline Homoseksual & 0,49 & $0,30-0,80$ & 0,00 \\
\hline$\underline{\text { IDU }}$ & 1,60 & $0,79-3,26$ & 0,20 \\
\hline
\end{tabular}

\section{BAHASAN}

Besaran masalah loss to follow up di RSUP dr Sardjito dapat dilihat dari Incidence Rate (IR) loss to follow up. IR pasien HIV yang mengalami loss to follow up terapi ARV dalam periode tahun 2011-2014 di RSUP dr Sardjito adalah 1,71 per 100 person month. Hal ini berarti bahwa dalam 100 orang pasien yang diterapi ARV dalam 1 bulan, maka akan ada 1-2 pasien yang mengalami loss to follow up. IR ini lebih tinggi dibandingkan dari penelitian di YKP Bali yaitu 5,5 per 100 person years dalam kurun waktu 10 tahun. Perbedaan ini terjadi karena karakteristik pasien HIV di YKP Bali berbeda dengan di RSUP dr. Sardjito. Sebagian besar pasien di YKP merupakan kelompok PS (pekerja seks) yang didukung dengan program outreach. Klinik yang memiliki outreach cenderung memiliki LTFU yang rendah (10).

Median time loss to follow up terjadi pada bulan ke 48,2 yang berarti bahwa 50\% pasien yang menerima terapi ARV terjadi pada bulan ke 48,2. Hal ini berbeda dengan penelitian Togun bahwa median time loss to follow up terjadi pada bulan ke 5,4 selama menjalani pengobatan (11). Perbedaan ini disebabkan karena $40 \%$ dari pasien yang mengalami loss to follow up tidak membuka statusnya pada keluarga ataupun teman dekat sehingga tidak ada dukungan yang diterima. Di RSUP dr Sardjito, terdapat Lembaga Swadaya Masyarakat (LSM) yang memberikan dukungan bagi pasien, baik yang sudah diketahui statusnya oleh keluarga dan teman ataupun tidak sehingga median time baru tercapai setelah bulan ke 48,2.

Analisis bivariat menunjukkan umur $\geq 46$ berisiko terhadap kejadian loss to follow up terapi ARV pada pasien HIV dibandingkan umur lain. Namun, pada analisis multivariat, tidak ditemukan hubungan antara umur $\geq 46$ terhadap kejadian loss to follow up terapi ARV pada pasien HIV. Hal ini menandakan terdapat hubungan yang lemah antara umur dengan loss to follow up. Pada usia tersebut, lemahnya kemampuan fisik untuk mengakses layanan kesehatan sehingga membutuhkan bantuan orang lain/ anak untuk mengantar ke fasilitas pelayanan kesehatan. Hal ini sangat berdampak pada kepatuhan dalam melakukan pengobatan. Selain itu, adanya kematian pada umur tersebut yang tidak dilaporkan sehingga tercatat sebagai loss to follow up.

Hasil penelitian Ubra menunjukkan bahwa responden yang tidak patuh berobat adalah pada kelompok usia tua yaitu sebesar $56.1 \%$ dan usia muda 43.9\% (12).Hasil penelitian ini tidak sejalan dengan penelitian oleh Saka yang menyatakan bahwa loss to 
follow up lebih berisiko pada pasien HIV yang memulai terapi ARV pada umur di bawah 35 tahun. Hal ini disebabkan karena pada umur yang lebih muda untuk terjadi loss to follow up dikaitkan dengan kondisi psikologis dalam menerima status HIV (13).

Selain umur, jenis kelamin adalah salah satu karakteristik dari individu yang memengaruhi pengambilan keputusan karena berhubungan dengan sifat yang melekat pada individu tersebut. Hasil penelitian tidak menemukan hubungan yang signifikan antara jenis kelamin dengan kejadian loss to follow up. Hal ini disebabkan karena, kejadian loss to follow up mungkin terjadi karena penyebab lain di luar jenis kelamin. Hasil penelitian ini tidak sejalan dengan penelitian Oku yang menyatakan bahwa laki-laki lebih berisiko untuk terjadi loss to follow up dibandingkan perempuan (14). Hal tersebut karena perempuan cenderung lebih memperhatikan masalah kesehatan dibandingkan laki-laki. Selain itu telah ada layanan kesehatan khusus bagi perempuan terutama masalah kesehatan reproduksi dan anak, sementara belum ada layanan kesehatan khusus laki-laki (6).

Pendidikan sangat berkaitan erat dengan pengetahuan yang memengaruhi pola pikir seseorang. Semakin tinggi tingkat pendidikan seseorang, semakin baik pula pengetahuan yang dimiliki. Pasien HIV dengan pendidikan lebih tinggi cenderung berpikir jangka panjang, memikirkan ancaman yang akan didapat jika tidak melanjutkan terapi, lebih mudah menerima informasi baik dari media massa, kampanye, atau nasehat orang lain sehingga memengaruhi perilaku mengikuti terapi (10).

Hasil penelitian menunjukkan tidak ada hubungan antara pendidikan dengan kejadian loss to follow up pasien HIV. Namun, jika dilihat dengan proporsi, pasien HIV dengan pendidikan tinggi sebagian besar berada pada kelompok yang tidak loss to follow up dibandingkan dengan kelompok loss to follow up. Hal tersebut sejalan dengan penelitian Sasaki yang menunjukkan bahwa tidak ada hubungan pendidikan dengan kepatuhan pengobatan ARV pada 6 bulan pertama awal terapi (15). Namun, hasil penelitian ini tidak sejalan dengan penelitian Khrisnan yang menyatakan bahwa loss to follow up lebih banyak pada ODHA dengan pendidikan lebih rendah (16).

Pekerjaan tertentu rentan terhadap kejadian loss to follow up. Hal ini disebabkan karena kesibukan yang terus menerus setiap hari sehingga tidak mempunyai waktu untuk berobat ke fasilitas kesehatan. Pasien yang masih berstatus sebagai mahasiswa lebih berisiko mengalami loss to follow up karena kesibukan kuliah sehingga cenderung melewatkan pengobatannya.
Penyebab lain bagi mahasiswa yang loss to follow up adalah sebagian besar mahasiswa berasal dari daerah di luar Yogyakarta. Apabila pendidikan telah selesai, mahasiswa kembali ke daerah masing-masing dan tidak meminta izin atau rujukan di rumah sakit. Sejalan dengan penelitian Amberbir, 18,2\% pasien HIV selalu melewatkan pengobatan atau tidak minum obat dengan alasan yang sibuk (17). Demikian pula hasil penelitian Oku yang menjelaskan bahwa 43.8\% pasien HIV tidak melakukan pengobatan karena alasan faktor kesibukan dalam melakukan pekerjaan (14).

Jarak rumah dengan pelayanan kesehatan menunjukkan ketersediaan dan askes pelayanan kesehatan di daerah tersebut. Jarak rumah yang jauh dengan fasilitas kesehatan untuk mengakses ARV memiliki kontribusi untuk kejadian loss to follow up. Hasil penelitian menunjukkan jarak rumah $\geq 10 \mathrm{~km}$ 1.51 kali berisiko mengalami loss to follow up terapi ARV. Hasil penelitian ini sejalan dengan penelitian lain yang menunjukkan bahwa jarak rumah $\geq 10 \mathrm{~km} \mathrm{1,28}$ kali meningkatkan risiko kejadian loss to follow up (18).

Salah satu penghambat dalam mengakses ARV meliputi jarak dengan pelayanan kesehatan, biaya transportasi dan waktu yang dibutuhkan untuk ke pelayanan kesehatan. Seseorang dengan jarak rumah yang jauh dengan layanan ARV akan sulit mengakses layanan karena berhubungan dengan waktu tempuh, ketersediaan sarana dan biaya transportasi serta motivasi yang tinggi untuk ke layanan kesehatan (19).

Faktor penyebab yang paling umum bagi pasien yang tidak datang ke fasilitas pelayanan kesehatan untuk melakukan pengobatan ARV adalah jarak yang cukup jauh dan sarana transportasi yang kurang (20). Hal ini berkaitan dengan kondisi geografis yang merupakan pedesaan sehingga akses ke pelayanan kesehatan sangat sulit.

Pasien menggunakan cara umum atau membayar secara mandiri dan menggunakan jaminan kesehatan. Kepatuhan sering dikaitkan dengan beban ekonomi yang harus ditanggung pada pengobatan yang bersifat seumur hidup bagi pasien HIV yang tidak memiliki jaminan kesehatan. Namun, hasil penelitian menunjukkan mereka yang menggunakan jaminan kesehatan lebih berisiko terhadap kejadian loss to follow up terapi ARV. Jenis jaminan kesehatan yang digunakan pasien HIV adalah Jaminan Kesehatan Masyarakat (Jamkesmas), Asuransi Kesehatan (Askes), Jaminan Sosial Tenaga Kerja (Jamsostek) maupun Jaminan kesehatan Nasional (JKN). Kendala yang dihadapi dalam penggunaan jaminan kesehatan yang memengaruhi kepatuhan pasien berhubungan dengan sistem layanan 
kesehatan yang berbelit-belit, waktu tunggu lama dan kesulitan akses dalam pelayanan kesehatan.

Penelitian Komisi Penanggulangan AIDS Nasional menjelaskan bahwa pasien yang menggunakan jaminan kesehatan seperti JPS masih merasa prosedur untuk memperoleh perawatan masih berbelit-belit atau rumit terutama bila klien tidak didampingi oleh seorang pendamping (keluarga, case manager, dan LSM) (21). Selain itu, proses pengurusan JPS atau Askes masih birokratis, panjang, banyak persyaratan dan juga membutuhkan biaya.

Kelompok risiko tinggi adalah kelompok populasi tertentu yang mempunyai risiko lebih tinggi untuk terpapar dan menderita HIV dibanding kelompok populasi lain yang disebabkan oleh perilaku beesiko infeksi HIV. Kelompok homoseksual merupakan faktor protektif untuk kejadian loss to follow up dengan kata lain risikonya sangat rendah. Hal ini disebabkan karena kelompok homoseksual yang berobat di RSUP dr. Sardjito pada umumnya usia muda yang lebih well educated sehingga memiliki pengetahuan tentang manfaat ARV lebih baik. Komunitas diantara mereka serta kelompok dukungan sebaya dengan tingkat solidaritas yang tinggi dan sangat peduli dengan HIV dapat saling mendukung dan mengingatkan untuk melakukan pengobatan. Selain itu, dapat berperan PMO bagi anggota yang lain. Dengan demikian, hal ini berdampak positif pada kepatuhan pengobatan.

Hasil penelitian ini tidak sejalan dengan Hermanides yang menunjukkan 87\% pasien HIV yang menerima pelayanan ART kombinasi pada kelompok risiko tinggi heteroseksual mengalami loss to follow up (22). Berbeda pula dengan penelitian Widyanthini, bahwa kejadian loss to follow up sebagian besar pada heteroseksual yaitu pekerja seks pendatang yang datang dari luar Bali (mobilitas tinggi) (10).

Kadar CD4 menggambarkan tingkat keparahan dari penyakit HIV. Hasil penelitian menunjukkan bahwa kadar CD4 tidak berhubungan dengan kejadian loss to follow up karenaproporsi pasien dengan kadar CD4 yang tinggi, sedang dan rendah tidak jauh berbeda. Hal ini menandakan bahwa kadar CD4 bukan faktor risiko loss to follow up.

Berbeda dengan penelitian Togun didapatkan pasien yang loss to follow-up mayoritas memiliki CD4 rendah ( $<100 \mathrm{sel} / \mathrm{mm} 3)(12)$. Hal tersebut karena pasien yang memiliki kadar CD4 rendah memiliki kecenderungan mortalitas lebih tinggi. Lain pula dengan penelitian Khrisnan yang menjelaskan bahwa pasien yang memulai terapi ARV dengan kadar CD4 lebih tinggi cenderung akan lebih rajin datang ke klinik dan meneruskan terapi ARV karena trend CD4 akan cenderung meningkat karena sudah merasakan manfaat terapi ARV (16). Sebaliknya apabila trend CD4 cenderung turun maka kemungkinan penderita HIV akan mencari pengobatan lain dan tidak meneruskan terapi. Hal ini menunjukkan terdapat masalah kesehatan yang kompleks dan tekanan psikososial.

WHO-stage adalah tingkatan dari stadium klinik penyakit HIV. Peningkatan stadium pada HIV juga menunjukkan peningkatan gejala dan keparahan. Pada stadium III dan IV, sudah nampak gejala klinik yang jelas. Hasil analisis bivariat menunjukkan bahwa stadium III dan IV berisiko untuk terjadi loss to follow up. Namun, analisis multivariat tidak menemukan hubungan antara stadium penyakit dengan loss to follow up. Dengan demikian, WHO-stage mempunyai hubungan yang lemah dengan kejadian loss to follow up. Hal ini disebabkan karena pasien dengan stadium III atau IV, tidak memungkinkan untuk melakukan kunjungan ke fasilitas kesehatan karena kondisi fisik yang lemah sehingga cenderung pasrah pada keadaan.

Penelitian ini tidak sejalan dengan penelitian Tedesse yang menunjukkan bahwa WHO-stage berhubungan dengan kejadian loss to follow up (23). Semakin tinggi stadium penyakit maka semakin berisiko untuk terjadi loss to follow up. Demikian pula hasil penelitian Mberi menyatakan bahwa $63 \%$ pasien HIV loss to follow up pada stage III dan IV (24). Hal ini disebabkan karena kondisi pasien sudah mulai parah dan memungkinkan untuk tidak melakukan pengobatan ke fasilitas kesehatan.

Koinfeksi adalah penyakit penyerta yang sering terjadi pada penderita HIV. Koinfeksi ini dapat menggambarkan stadium penyakit HIV. Hasil penelitian menunjukkan tidak ada hubungan antara adanya koinfeksi dengan kejadian loss to follow up. Adanya koinfeksi menunjukkan bahwa pasien HIV telah berada pada stadium yang lebih parah. Hal ini menyebabkan pasien merasa lebih penting untuk melakukan pengobatan dan meningkatkan kepatuhan sehingga kondisi kesehatan cenderung membaik. Penelitian Widyanthini menyatakan bahwa tidak ditemukan hubungan antara infeksi oportunistik dengan loss to follow up (20). Berbeda dengan penelitian Melloni bahwa pasien yang mempunyai koinfeksi TB pada awal terapi ARV berhubungan signifikan dengan kejadian loss to follow up (11).

Regimen ARV adalah jenis obat yang dikonsumsi dalam pengobatan atau terapi HIV. Hal ini disebabkan karena efek samping memengaruhi kejadian loss to follow up karena efek samping obat yang menimbulkan ketidaknyamanan dan masalah lain dari tahap ringan sampai berat pada pemakaian jenis obat tertentu. Hasil 
penelitian menunjukkan tidak ada hubungan antaran regimen ARV dengan kejadian loss to follow up. Hal ini disebabkan karena efek samping yang diakibatkan oleh regimen tertentu bersifat sementara pada awal pengobatan danidukung pula oleh konseling kepatuhan yang dilakukan pada awal terapi mengenai efek samping obat yang dapat diantisipasi.

Apabila keluhan efek samping obat masih berlanjut dilakukan subtitusi dengan regimen lain sehingga pasien terus melanjutkan pengobatan. Selain itu, apabila keluhan efek samping obat masih berlanjut dilakukan subtitusi dengan regimen lain. Sejalan dengan penelitian yang dilakukan Luigia menjelaskan bahwa $46,6 \%$ alasan penggantian obat karena pasien yang mengalami efek samping obat (25). Dengan demikian pasien dapat terus melanjutkan pengobatan.

Hasil penelitian ini tidak sejalan dengan penelitian Tadesse menyatakan bahwa regimen AZT-3TC-NVP 3.5 kali meningkatkan risiko loss to follow up dibandingkan dengan yang mengonsumsi d4t (30)-3TC-NVP (23). Efek samping berupa supresi sumsum tulang yang diinduksi obat, seperti anemia dan neutropenia dapat terjadi pada penggunaan AZT, adanya rash dan efek samping lain pada penggunaan NVP (24).

\section{SIMPULAN}

Faktor risiko loss to follow up terapi ARV pada pasien HIV di RSUP Dr. Sardjito tahun 2011-2014 adalah seorang mahasiswa, jarak rumah dengan layanan ARV $>10 \mathrm{~km}$ dan cara pembayaran menggunakan jaminan kesehatan. Kelompok homoseksual sebagai faktor protektif terjadinya loss to follow up pada pasien HIV.

Pihak RSUP Dr. Sardjito khususnya klinik VCT diharapkan meningkatkan konseling kepatuhan terutama pasien mahasiswa dalam rangka peningkatan kepatuhan terapi baik itu selama menjalani terapi di RSUP Dr. Sardjito maupun bila kembali ke daerah asal.

Kerja sama dengan pendamping pasien atau Pengawas Minum Obat (PMO) untuk memantau kepatuhan pengobatan pasien dan desentralisasi layanan ARV, sehingga memudahkan akses ARV. Selain itu, perlu peningkatan kualitas pelayanan efektif dan efisien pada pasien HIV yang menggunakan jaminan kesehatan.

Peneliti selanjutnya perlu mengkaji mengenai faktor lain yang belum dikaji dalam penelitian ini, seperti dukungan keluarga dan sosial serta perilaku yang berhubungan dengan loss to follow up.

\section{Abstrak}

Tujuan: Penelitian ini bertujuan untuk mengetahui faktor risiko loss to follow up terapi ARV pada Pasien HIV di RSUP Dr. Sardjito Yogyakarta Tahun 2011-2014. Metode: Penelitian ini merupakan penelitian kohort retrospektif dengan melibatkan 499 pasien HIV. Observasi dilakukan selama empat tahun menggunakan data rekam medis. Analisis data menggunakan Kaplan-Meier dan cox proportional hazards regression. Hasil: Terdapat 190 Pasien yang loss to follow up. Faktor risiko loss to follow up terapi ARV yang ditemukan adalah mahasiswa $(\mathrm{AHR}=2,42 ; 95 \% \quad \mathrm{CI}=1,20-4,89)$, jarak rumah $\geq 10 \mathrm{~km}$ (AHR=1,58; 95\% CI=1,09-2,31), menggunakan jaminan kesehatan (AHR=1,67; 95\% $\mathrm{CI}=1,11-2,51)$ dan homoseksual sebagai faktor protektif loss to follow up terapi ARV (HR=0,49; 95\% $\mathrm{CI}=0,30-0,80)$. Simpulan: Berstatus mahasiswa, jarak rumah $\geq 10 \mathrm{~km}$ dan menggunakan jaminan kesehatan adalah faktor risiko loss to follow up terapi ARV. Perlu peningkatan konseling kepatuhan pada mahasiswa, kerjasama dengan pendamping pasien dan desentralisasi layanan ARV, pelayanan efektif dan efisien pada pasien yang menggunakan jaminan kesehatan.

Kata Kunci: loss to follow up; ARV; HIV

\section{PUSTAKA}

1. WHO. 10 Facts on HIV/AIDS. Available at: http://www.who.int/features/factfiles/hiv/en/. [Diakses 29 Juli 2016].

2. Ditjen PP \& PL Kemenkes RI. (2015). Laporan Perkembangan Pengendalian HIV-AIDS Triwulan III. Jakarta: Kemenkes RI. 2015.

3. KPA Provinsi DIY. (2015). Data Kasus HIV \& AIDS DIY s.d. Triwulan 1 Tahun 2015, Available at: http://aidsyogya.or.id/category/data-hiv-aids/. [Diakses 29 Juli 2016].

4. Permenkes RI No. 87 Tahun 2014 tentang Pedoman Pengobatan Antiretroviral. Kemenkes RI. Jakarta.

5. Hønge BL, Jespersen S, Nordentoft PB, Medina C, da Silva D, da Silva ZJ, Østergaard L, Laursen AL, Wejse C, Bissau HIV cohort study group. Loss to follow-up occurs at all stages in the diagnostic and follow-up period among HIV-infected patients in Guinea-Bissau: a 7-year retrospective cohort study. BMJ open. 2013 Oct 1;3(10):e003499. Available at: http://www.ncbi.nlm.nih.gov [Diakses 28 Desember 2015].

6. Odafe S, Idoko O, Badru T, Aiyenigba B, Suzuki C, Khamofu H, Onyekwena O, Okechukwu E, Torpey K, Chabikuli ON. Patients' demographic and clinical characteristics and level of care associated with lost to follow-up and mortality in adult patients on first-line ART in Nigerian hospitals. 
Journal of the International AIDS Society. 2012 Apr 1;15(2). Available at: http://www.jiasociety.org/. [Diakses 14 Desember 2015].

7. Bekolo CE, Webster J, Batenganya M, Sume GE, Kollo B. Trends in mortality and loss to follow-up in HIV care at the Nkongsamba Regional hospital, Cameroon. BMC research notes. 2013 Dec;6(1):512. Available at: http://www.biomedcentral.com/ [Diakses 7 September 2015].

8. Zhou J, Tanuma J, Chaiwarith R, Lee CK, Law MG, Kumarasamy N, Phanuphak P, Chen YM, Kiertiburanakul S, Zhang F, Vonthanak S. Loss to followup in HIV-infected patients from Asia-Pacific region: Results from TAHOD. AIDS research and treatment. 2012;2012.. Available at: http://www.hindawi.com/ [Diakses 28 Desember 2015].

9. Mahardining AB. Hubungan Antara Pengetahuan, Motivasi, Dan Dukungan Keluarga Dengan Kepatuhan Terapi Arv Odha. KEMAS: Jurnal Kesehatan Masyarakat. 2010;5(2). Available at: http://www.journal.unnes.ac.id.

10. Widyanthini DN. Faktor-Faktor Yang Berhubungan Dengan Loss To Follow Up Pada ODHA Yang Menerima Terapi ARV Di Klinik Amertha Yayasan Kerti Praja Bali Tahun 2002-2012. Skripsi. Denpasar: Universitas Udayana. Available at: http://www.pps.unud.ac.id/[Diakses 24 Mei 2015].

11. Togun T, Peterson I, Jaffar S, Oko F, Okomo U, Peterson K, Jaye A. Pre-treatment mortality and loss-to-follow-up in HIV-1, HIV-2 and HIV-1/HIV-2 dually infected patients eligible for antiretroviral therapy in The Gambia, West Africa. AIDS research and therapy. 2011 Dec;8(1):24. Available at: http://www.ncbi.nlm.nih.gov/ [diakses 28 Desember 2015].

12. Ubra RR. Faktor-faktor yang Berhubungan dengan Kepatuhan Pengobatan Minum ARV pada Pasien HIV di Kabupaten Mimika-Provinsi Papua Tahun 2012. Universitas Indonesia. 2012.

13. Saka B, Landoh DE, Patassi A, d'Almeida S, Singo A, Gessner BD, Pitché PV. Loss of HIV-infected patients on potent antiretroviral therapy programs in Togo: risk factors and the fate of these patients. Pan African Medical Journal. 2013;15(1). Available at: http://www.panafrican-med-journal.com/ [Diakses 28 Desember 2015].

14. Ochieng-Ooko V, Ochieng D, Sidle JE, Holdsworth M, Wools-Kaloustian K, Siika AM, Yiannoutsos CT, Owiti M, Kimaiyo S, Braitstein P. Influence of gender on loss to follow-up in a large HIV treatment programme in western Kenya. Bulletin of the World Health Organization. 2010;88:681-8. Available at: http://www.ncbi.nlm.nih.gov/. [Diakses 7 September 2015].

15. Sasaki Y, Kakimoto K, Dube C, Sikazwe I, Moyo C, Syakantu G, Komada K, Miyano S, Ishikawa N, Kita K, Kai I. Adherence to antiretroviral therapy (ART) during the early months of treatment in rural Zambia: influence of demographic characteristics and social surroundings of patients. Annals of clinical microbiology and antimicrobials. 2012 Dec;11(1):34. Available

At: http://www.ann-clinmicrob.com/ [Diakses 22 Juli 2016].

16. Krishnan S, Wu K, Smurzynski M, Bosch RJ, Benson CA, Collier AC, Klebert MK, Feinberg J, Koletar SL, ALLRT/A5001 Team. Incidence rate of and factors associated with loss to follow-up in a longitudinal cohort of antiretroviral-treated HIV-infected persons: an AIDS Clinical Trials Group (ACTG) Longitudinal Linked Randomized Trials (ALLRT) analysis. HIV clinical trials. 2011 Aug 1;12(4):190-200. Available at: http://www.ncbi.nlm.nih.gov/ [Diakses 28 Desember 2015].

17. Amberbir A, Woldemichael K, Getachew S, Girma B, Deribe K. Predictors of adherence to antiretroviral therapy among HIV-infected persons: a prospective study in Southwest Ethiopia. BMC Public Health. 2008 Dec;8(1):265. Available

http://www.biomedcentral.com/1471-2458/8/265. [Diakses 7 September 2015].

18. Shaweno T, Shaweno D. When are patients lost to follow-up in pre-antiretroviral therapy care? a retrospective assessment of patients in an Ethiopian rural hospital. Infectious diseases of poverty. 2015 Dec;4(1):27. Available at: http:/www.ncbi.nlm.nih.gov/. [Diakses 24 September 2015].

19. Govindasamy D, Ford N, Kranzer K. Risk factors, barriers and facilitators for linkage to antiretroviral therapy care: a systematic review. Aids. 2012 Oct 23;26(16):2059-67. Available at: http://www.ncbi.nlm.nih.gov/ [Diakses 7 September 2015].

20. Geng EH, Bangsberg DR, Musinguzi N, Emenyonu N, Bwana MB, Yiannoutsos CT, Glidden DV, Deeks SG, Martin JN. Understanding reasons for and outcomes of patients lost to follow-up in antiretroviral therapy programs in Africa through a sampling-based approach. Journal of acquired immune deficiency syndromes (1999). 2010 Mar;53(3):405., Available at: http://www.ncbi.nlm.nih.Gov/pmc/articles/PMC360 6953/. [Diakses 22 Juli 2016].

21. KPAN-UNAIDS.Penelitian Partisipatif: ODHA \& Akses Pelayanan Kesehatan Dasar. 2005. Available at: http://spiritia.or.id/Dok/odhaakses.pdf. [Diakses 6 Agustus 2016].

22. Hermanides H, Holman R, Gras L, Winkel C, Gerstenbluth I, de Wolf F, Duits A. Loss to follow-up and mortality rates in HIV-1-infected patients in Curaçao before and after the start of combination antiretroviral therapy. AIDS research and human retroviruses. 2013 Oct 1;29(10):1300-5. Available at: http://www.rug.nl/. [Diakses 24 September 2015].

23. Tadesse K, Fisiha H. Predictors of Loss to Follow Up of Patients Enrolled on Antiretroviral Therapy: A Retrospective Cohort Study. J AIDS Clin Res. 2014;5(393):2. Available http://dx.doi.org/10.4172/2155-6113.1000393. [Diakses 24 September 2015].

24. Mberi MN, Kuonza LR, Dube NM, Nattey C, Manda S, Summers R. Determinants of loss to follow-up in patients on antiretroviral treatment, South Africa, 2004-2012: a cohort study. BMC health services research. 2015 Dec;15(1):259. Available at: http://www.ncbi.nlm.nih.gov/

25. Elzi L, Marzolini C, Furrer H, Ledergerber B, Cavassini M, Hirschel B, Vernazza P, Bernasconi E, Weber R, Battegay M. Treatment modification in human immunodeficiency virus-infected individuals starting combination antiretroviral therapy between 2005 and 2008. Archives of internal medicine. 2010 Jan 1;170(1):57-65. 